\title{
Effect of Weed Management Practices in Rabi Maize and their Residual Effect on Succeeding Greengram
}

\author{
B. Sandhya Rani*, V. Chandrika, G. Prabhakara Reddy, P. Sudhakar, \\ K. V. Nagamadhuri and G. Karuna Sagar \\ Department of Agronomy, S. V. Agricultural College, Tirupati- 517502, \\ Andhra Pradesh, India \\ *Corresponding author
}

\section{A B S T R A C T}

\section{Keywords}

Weed management, Maize, Growth, Yield, Succeeding greengram

Article Info

Accepted:

10 November 2019

Available Online:

10 December 2019
Field experiment was conducted during rabi and summer, 2018-19 at wetland farm of S.V. Agricultural College, Tirupati, Andhra Pradesh. The experiment was laid out in a randomized block design with three replications. There were 10 treatments consisting of pre emergence application of atrazine @ $1.0 \mathrm{~kg}$ a.i ha ${ }^{-1} \mathrm{fb}$ post emergence application of tembotrione @ $120 \mathrm{~g}$, topramezone @ $30 \mathrm{~g}$, halosulfuron methyl @67.5 g, 2,4-D amine salt @ $580 \mathrm{~g}$, tembotrione @60g + 2,4-D amine salt@290 g, topramezone@15g + 2,4-D amine salt @ 290 g, halosulfuron methyl@34 g a.i ha ${ }^{-1}+2,4-\mathrm{D}$ amine salt @290 g a.i ha ${ }^{-1}$, pre emergence application of atrazine @ $1.0 \mathrm{~kg}$ a.i ha ${ }^{-1} \mathrm{fb}$ one HW at 30 DAS, hand weeding twice at 15 and 30 DAS and control. The higher kernel yield of maize was recorded with hand weeding twice at 15 and 30 DAS $\left(T_{9}\right)$, which was however comparable with application of atrazine@1.0 kg a.i ha ${ }^{-1}$ as pre emergence $f b$ topramezone @ $30 \mathrm{~g}$.i ha ${ }^{-1}$ as post emergence $\left(\mathrm{T}_{3}\right)$, atrazine @ 1.0 $\mathrm{kg}$ a.i ha ${ }^{-1}$ as pre emergence $f b$ tembotrione @ $120 \mathrm{~g}$ a.i ha ${ }^{-1}$ as post emergence $\left(\mathrm{T}_{2}\right)$, atrazine @ $1.0 \mathrm{~kg}$ a.i ha ${ }^{-1}$ as pre emergence $f b$ one HW at $30 \mathrm{DAS}\left(\mathrm{T}_{1}\right)$, without any significant disparity among them.

\section{Introduction}

Maize is popularly known as "queen of cereals". The versatile nature of the crop allows it to grow across wide range of agroecological regions of the country. In India maize is cultivated in an area of $9.2 \mathrm{M}$ ha with the production of $28.7 \mathrm{Mt}$ and productivity of
$3.12 \mathrm{t} \mathrm{ha}^{-1}$ (www.indiastat.com, 2018). In India $23.5 \%$ of maize is used as human food, $51 \%$ as poultry feed, $12 \%$ as animal feed, $12 \%$ as industrial (starch) products, beverages and seed (1\% each) (Dass et al., 2008). Wider row spacing and slow growth nature of the crop during the initial stages makes it highly susceptible to weeds especially during the 
initial stages of crop growth. Imoloame and Omolaiye (2017) observed that weed interference in maize from 3-6 WAS significantly depressed the growth parameters and grain yield of maize. Yogita et al., (2018) visualized that potential yield loss in maize due to weeds ranged from 18 - 65 per cent.

Weed flora in maize have been traditionally controlled with hand weeding but in the recent years due to scarcity of labour, application of herbicides is inevitable to control them. Pre emergence application of atrazine is the commonly followed practice to control the weeds during initial stages but atrazine was not equally effective for controlling all the types of weeds in the field especially grasses and sedges after 20 DAS. Repeated usage of same group of herbicide leaves herbicide residues in the soil besides developing resistance in the weeds. Therefore usage of pre and post emergence herbicide with temporal variation may help in avoiding the problem of weeds during the later stages of crop growth also. Mixing of two or more herbicides keeping compatibility in account can help to broaden weed control spectrum and reducing active ingredient requirement (Baghestani et al., 2008).

Sometimes herbicides used in previous crop may limit the growth and yield of succeeding crops. In light of the above the present investigation was under taken to formulate an appropriate weed management practice in maize and to study the residual effect of herbicides on yield attributes and yield of succeeding greengram crop.

\section{Materials and Methods}

An experiment was conducted during rabi and summer, 2017-18 at wetland farm of S.V. Agricultural College, Tirupati, Andhra Pradesh. The farm is geographically situated at $13.6^{\circ} \mathrm{N}$ latitude and $79.3^{\circ} \mathrm{E}$ longitude, at an altitude of $182.9 \mathrm{~m}$ above the mean sea level in the Southern Agro-Climatic Zone of Andhra Pradesh. The soil of the experimental site was sandy clay loam in texture, neutral in soil reaction, low in organic carbon $(0.25 \%)$ and available nitrogen, medium in available Phosphorus and potassium. The experiment consists of 10 treatments laid out in a randomized block design with three replications. The treatments were atrazine @ $1.0 \mathrm{~kg} \mathrm{a.i} \mathrm{ha}{ }^{-1}$ as pre emergence $f b$ one HW at 30 DAS $\left(\mathrm{T}_{1}\right)$, atrazine @ $1.0 \mathrm{~kg} \mathrm{a.i} \mathrm{ha}{ }^{-1}$ as pre emergence $f b$ tembotrione @ $120 \mathrm{~g}$ a.i ha ${ }^{-1}$ as post emergence $\left(\mathrm{T}_{2}\right)$, atrazine @ $1.0 \mathrm{~kg} \mathrm{a.i} \mathrm{ha}{ }^{-1}$ as pre emergence $f b$ topramezone @ $30 \mathrm{~g}$ a.i $\mathrm{ha}^{-1}$ as post emergence $\left(\mathrm{T}_{3}\right)$, atrazine @ $1.0 \mathrm{~kg}$ a.i ha ${ }^{-1}$ as pre emergence $f b$ halosulfuron methyl @67.5 g a.i ha ${ }^{-1}$ as post emergence $\left(\mathrm{T}_{4}\right)$, atrazine @ $1.0 \mathrm{~kg}$ a.i ha ${ }^{-1}$ as pre emergence $f b$ 2, 4- D amine salt @ $580 \mathrm{~g}$ a.i $\mathrm{ha}^{-1}$ as post emergence $\left(\mathrm{T}_{5}\right)$, atrazine @ $1.0 \mathrm{~kg}$ a.i ha ${ }^{-1}$ as pre emergence $f b$ tembotrione @ 60g + 2,4-D amine salt @290 g a.i ha ${ }^{-1}$ as post emergence $\left(\mathrm{T}_{6}\right)$, atrazine @ $1.0 \mathrm{~kg} \mathrm{a.i} \mathrm{ha}{ }^{-1}$ as pre emergence $f b$ topramezone @ $15 \mathrm{~g}+$ 2,4-D amine salt @290 g a.i ha ${ }^{-1}$ as post emergence $\left(\mathrm{T}_{7}\right)$, atrazine @1.0 kg a.i ha ${ }^{-1}$ as pre emergence $f b$ halosulfuron methyl @ $34 \mathrm{~g}$ a.i ha ${ }^{-1}+2,4-\mathrm{D}$ amine salt @ $290 \mathrm{~g} \mathrm{a.i} \mathrm{ha}^{-1}$ as post emergence $\left(\mathrm{T}_{8}\right)$, hand weeding twice at 15 and 30 DAS $\left(T_{9}\right)$ and control $\left(T_{10}\right)$. The pre emergence herbicide was applied on the next day after sowing and early post emergence herbicides were are applied at 21 DAS when the weeds are at 2-3 leaf stage. The Maize variety DHM- 117 was sown on 09.11.18 during rabi 2018, with a spacing of $60 \mathrm{~cm}$ x 20 $\mathrm{cm}$ and subsequent green gram crop was sown on 08.03 .19 with a with a spacing of $30 \mathrm{~cm} \mathrm{x}$ $10 \mathrm{~cm}$. The gross plot size is $5.4 \times 4.6 \mathrm{~m}$.

A uniform dose of $240 \mathrm{~kg} \mathrm{~N}, 80 \mathrm{~kg} \mathrm{P}_{2} \mathrm{O}_{5}$ and $80 \mathrm{~kg} \mathrm{~K}_{2} \mathrm{O}$ ha $^{-1}$ was applied through urea, single super phosphate and muriate of potash, respectively to all the plots of maize and $20 \mathrm{~kg}$ $\mathrm{N}$ and $50 \mathrm{~kg}$ of $\mathrm{P}_{2} \mathrm{O}_{5}$ ha $^{-1}$ was applied through 
urea and single super phosphate to green gram crop. All other recommended management practices were followed to raise the crops. Weed sampling was done at random by placing a quadrant of $1 \mathrm{~m} \mathrm{x} 1 \mathrm{~m}$ in each plot and the number of weeds species were counted and expressed as no. $\mathrm{m}^{-2}$ and dry weight of total weeds was recorded after drying and expressed as $\mathrm{g} \mathrm{m}^{-2}$. In view of larger variation in the recorded values of density and dry weight of weeds, the corresponding data were subjected to square root transformation $(\sqrt{ } 0.5+\mathrm{x})$ and the corresponding transformed values were used for statistical analysis as suggested by Gomez and Gomez (1984). Observations on growth and yield attributes of maize and succeed in green gram was recorded at the time of harvest and the data was statistically analyzed following the analysis of variance for randomized block design as suggested by Panse and Sukhatme (1985). Statistical significance was tested with ' $F$ ' test at 5 per cent level of probability and compared the treatmental means with critical difference.

\section{Results and Discussion}

\section{Weed flora}

The predominant weed species in the experimental site were Bracharia ramose, Cyonodon dactylon, Dactyloctenium aegyptium (L) Beauv, Digitaria sanguinalis (L.) scop, Cyperus rotundus L, Boerhavia erecta L, Borreria hispida (L.) K. Schum, Celosia argentea L., Cleome viscosa L., Clitoria ternata L., Commelina benghalensis L., Corchorus aestuans L., Digera arvensis, Euphorbia hirta L., Phyllanthus niruri L., Trichodesma indicum L. and Tridax procumbens L. Similar type of weed flora was recorded at Rajendranagar, Hyderabad by Pradeep et al., (2017).
Effect of weed management practices on maize

The taller plants with higher plant height, leaf area index and dry matter production of maize at harvest was recorded with hand weeding twice at 15 and 30 DAS $\left(\mathrm{T}_{9}\right)$, which was however comparable with application of atrazine@1.0 kg a.i ha ${ }^{-1}$ as pre emergence $f b$ topramezone @ 30 g a.i ha ${ }^{-1}$ as post emergence $\left(\mathrm{T}_{3}\right)$, atrazine @ $1.0 \mathrm{~kg}$ a.i ha ${ }^{-1}$ as pre emergence $f b$ tembotrione @ $120 \mathrm{~g} \mathrm{a.i} \mathrm{ha}^{-1}$ as post emergence $\left(\mathrm{T}_{2}\right)$, atrazine @ $1.0 \mathrm{~kg}$ a.i $\mathrm{ha}^{-1}$ as pre emergence $f b$ one HW at 30 DAS $\left(\mathrm{T}_{1}\right)$, without any significant disparity among them. This could be mainly due to the reduced weed density and growth thus providing weed free environment due to which all the growth resources were optimally utilized by the crop plants for better vegetative growth that reflected as plant height and dry matter production as reported by Mitra et al., (2018). However atrazine @ $1.0 \mathrm{~kg}$ a.i ha ${ }^{-1}$ as pre emergence $f b$ topramezone @ 15g + 2,4-D amine salt @290 g a.i ha ${ }^{-1}$ as post emergence $\left(\mathrm{T}_{7}\right)$ and atrazine @ $1.0 \mathrm{~kg}$ a.i ha ${ }^{-1}$ as pre emergence $f b$ tembotrione @ 60g + 2,4-D amine salt @290 g a.i ha ${ }^{-1}$ as post emergence $\left(\mathrm{T}_{6}\right)$ were statistically comparable with one another and were significantly superior to atrazine @1.0 kg a.i ha ${ }^{-1}$ as pre emergence $f b$

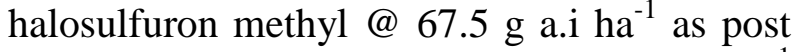
emergence $\left(\mathrm{T}_{4}\right)$ and atrazine @ $1.0 \mathrm{~kg}$ a.i ha ${ }^{-1}$ as pre emergence $f b$ 2, 4- D amine salt @ 580 $\mathrm{g}$ a.i ha ${ }^{-1}$ as post emergence $\left(\mathrm{T}_{5}\right)$, which inturn were comparable with one another.

Significantly lower plant, leaf area index and dry matter production was noticed with control $\left(\mathrm{T}_{10}\right)$. Growth was minimum under un weeded control due to severe weed competition that leaded to suppressed vegetative growth of maize. Similar results were reported by Nidhi et al., (2015). 
Table.1 Effect of different weed management practices growth, yield attributes and yield of maize

\begin{tabular}{|c|c|c|c|c|c|c|c|c|c|}
\hline \multirow{2}{*}{ Treatments } & \multirow[b]{2}{*}{$\begin{array}{l}\text { Plant } \\
\text { height } \\
(\mathbf{c m})\end{array}$} & \multirow[b]{2}{*}{$\begin{array}{l}\text { Leaf } \\
\text { Area } \\
\text { Index }\end{array}$} & \multirow[b]{2}{*}{$\begin{array}{c}\text { Dry } \\
\text { matter } \\
\text { production } \\
\left(\mathrm{kg} \mathrm{ha}^{-1}\right)\end{array}$} & \multirow[b]{2}{*}{$\begin{array}{l}\text { Cob } \\
\text { length } \\
(\mathbf{c m})\end{array}$} & \multirow[b]{2}{*}{$\begin{array}{l}\text { Cob } \\
\text { girth } \\
(\mathrm{cm})\end{array}$} & \multirow[b]{2}{*}{$\begin{array}{l}\text { Number } \\
\text { of kernel } \\
\text { row }^{-1}\end{array}$} & \multirow[b]{2}{*}{$\begin{array}{l}\text { Numb } \\
\text { er of } \\
\text { kernel } \\
\text { cob }^{-1}\end{array}$} & \multirow[b]{2}{*}{$\begin{array}{l}\text { Kernel } \\
\text { yield } \\
\left(\mathrm{kg} \mathrm{ha}^{-1}\right)\end{array}$} & \multirow[b]{2}{*}{$\begin{array}{l}\text { Straw } \\
\text { yield } \\
\left(\operatorname{kg~ha}^{-1}\right)\end{array}$} \\
\hline & & & & & & & & & \\
\hline $\begin{array}{l}\mathrm{T}_{1} \text { : Atrazine @ } 1.0 \mathrm{~kg} \text { a.i ha }{ }^{-1} \text { as PE } f b \text { one } \\
\text { HW at } 30 \text { DAS }\end{array}$ & 194 & 1.85 & 13366 & 20.21 & 17.03 & 31.00 & 462 & 7903 & 6963 \\
\hline $\begin{array}{l}\mathrm{T}_{2}: \text { Atrazine @ } 1.0 \mathrm{~kg} \text { a.i ha }{ }^{-1} \text { as PE } f b \\
\text { tembotrione @ } 120 \mathrm{~g} \text { a.i ha } \text { ha PoE }^{-1} \text { as Pon }\end{array}$ & 197 & 1.87 & 13401 & 20.24 & 17.40 & 31.27 & 469 & 7921 & 6980 \\
\hline $\begin{array}{l}\mathrm{T}_{3} \text { : Atrazine @1.0 kg a.i ha }{ }^{-1} \text { as PE } f b \\
\text { topramezone@ } 30 \mathrm{~g} \text {.i ha }{ }^{-1} \text { as PoE }\end{array}$ & 200 & 1.89 & 13601 & 20.85 & 17.53 & 31.33 & 470 & 8018 & 7084 \\
\hline $\begin{array}{l}\mathrm{T}_{4} \text { : Atrazine @ } 1.0 \mathrm{~kg} \text { a.i ha }{ }^{-1} \text { as PE } f b \\
\text { halosulfuron methyl @ } 67.5 \mathrm{~g} \mathrm{a.i} \mathrm{ha}^{-1} \text { as } \\
\text { PoE }\end{array}$ & 152 & 1.53 & 8791 & 16.35 & 12.20 & 25.60 & 386 & 5475 & 4817 \\
\hline $\begin{array}{l}\mathrm{T}_{5} \text { : Atrazine @ } 1.0 \mathrm{~kg} \text { a.i ha }{ }^{-1} \text { as PE } f b 2,4- \\
\mathrm{D} \text { amine salt @ } 580 \mathrm{~g} \text { a.i ha }{ }^{-1} \text { as PoE }\end{array}$ & 150 & 1.48 & 8625 & 16.27 & 12.03 & 25.57 & 383 & 5316 & 4809 \\
\hline $\begin{array}{l}\mathrm{T}_{6}: \text { Atrazine @ } 1.0 \mathrm{~kg} \text { a.i ha }{ }^{-1} \text { as PE } f b \\
\text { tembotrione @60g + 2,4-D amine salt @ } \\
290 \text { g a.i ha }{ }^{-1} \text { as PoE }\end{array}$ & 175 & 1.68 & 10682 & 18.27 & 14.30 & 27.98 & 415 & 6422 & 5683 \\
\hline $\begin{array}{l}\mathrm{T}_{7}: \text { Atrazine @ } 1.0 \mathrm{~kg} \text { a.i ha }{ }^{-1} \text { as PE } f b \\
\text { topramezone @ } 15 \mathrm{~g}+2,4-\mathrm{D} \text { amine salt @ } \\
290 \mathrm{~g} \text { a.i } \mathrm{ha}^{-1} \text { as PoE }\end{array}$ & 177 & 1.69 & 10537 & 18.29 & 14.47 & 28.12 & 422 & 6354 & 5760 \\
\hline $\begin{array}{l}\mathrm{T}_{8} \text { : Atrazine @ } 1.0 \mathrm{~kg} \text { a.i ha } \mathrm{ha}^{-1} \mathrm{PE} f b \\
\text { halosulfuron methyl @ } 34 \mathrm{~g} \text { a.i ha } \mathrm{ha}^{-1}+2,4-\mathrm{D} \\
\text { amine salt @ } 290 \mathrm{~g} \text { a.i ha }{ }^{-1} \text { as PoE }\end{array}$ & 130 & 1.32 & 7167 & 14.26 & 10.27 & 22.11 & 347 & 4616 & 4051 \\
\hline$T_{9}:$ Hand weeding twice at 15 and 30 DAS & 201 & 1.92 & 13853 & 20.96 & 17.60 & 31.93 & 471 & 8185 & 7168 \\
\hline$T_{10}:$ Weedy check & 113 & 0.88 & 5183 & 11.30 & 8.70 & 19.72 & 286 & 3461 & 2888 \\
\hline C.D $(P=0.05)$ & 16 & 0.13 & 855 & 1.89 & 1.47 & 1.84 & 27 & 562 & 640 \\
\hline SEm \pm & 5 & 0.04 & 255 & 0.63 & 0.49 & 0.61 & 9 & 188 & 214 \\
\hline
\end{tabular}

* PE- Pre emergence, PoE - Post emegence 
Table.2 Effect of different weed management practices yield attributes and yield of succeeding greengram

\begin{tabular}{|c|c|c|c|c|c|}
\hline Treatments & $\begin{array}{l}\text { No. of } \\
\text { pods } \\
\text { plant }^{-1}\end{array}$ & $\begin{array}{l}\text { No. of } \\
\text { seeds } \\
\text { pod }^{-1}\end{array}$ & $\begin{array}{l}\text { Seed } \\
\text { index } \\
(\mathrm{gm})\end{array}$ & $\begin{array}{c}\text { Seed } \\
\text { yield } \\
\left(\mathrm{kg} \mathrm{ha}^{-1}\right)\end{array}$ & $\begin{array}{c}\text { Haulm } \\
\text { yield } \\
\left(\mathrm{kg} \mathrm{ha}^{-1}\right)\end{array}$ \\
\hline $\begin{array}{l}\mathrm{T}_{1} \text { : Atrazine @ } 1.0 \mathrm{~kg} \mathrm{a.i} \mathrm{ha}^{-1} \text { as PE } f b \\
\text { one HW at } 30 \text { DAS }\end{array}$ & 12.30 & 12.23 & 12.27 & 637 & 628 \\
\hline $\begin{array}{l}\mathrm{T}_{2} \text { : Atrazine @ } 1.0 \mathrm{~kg} \mathrm{a.i} \mathrm{ha}^{-1} \text { as PE } f b \\
\text { tembotrione@ } 120 \mathrm{~g} \mathrm{a.i} \mathrm{ha}^{-1} \text { as PoE }\end{array}$ & 12.16 & 9.80 & 10.13 & 623 & 621 \\
\hline $\begin{array}{l}\mathrm{T}_{3} \text { : Atrazine @ } 1.0 \mathrm{~kg} \mathrm{a.i} \mathrm{ha}^{-1} \text { as PE } f b \\
\text { topramezone @ } 30 \mathrm{~g} \mathrm{a.i} \mathrm{ha}^{-1} \text { as PoE }\end{array}$ & 10.17 & 9.53 & 12.47 & 531 & 541 \\
\hline $\begin{array}{l}\mathrm{T}_{4} \text { : Atrazine @ } 1.0 \mathrm{~kg} \mathrm{a.i} \mathrm{ha}^{-1} \text { as PE } f b \\
\text { halosulfuron methyl @67.5 } \mathrm{g} \mathrm{a.i} \mathrm{ha}^{-1} \text { as } \\
\text { PoE }\end{array}$ & 8.23 & 0.37 & 1.12 & 536 & 525 \\
\hline $\begin{array}{l}\mathrm{T}_{5}: \text { Atrazine @ } 1.0 \mathrm{~kg} \mathrm{a.i} \mathrm{ha}^{-1} \text { as PE } f b \\
2,4 \text { - D amine salt @ } 580 \mathrm{~g} \mathrm{a.i} \mathrm{ha}^{-1} \text { as } \\
\text { PoE }\end{array}$ & 9.26 & 9.22 & 9.23 & 660 & 446 \\
\hline $\begin{array}{l}\mathrm{T}_{6} \text { : Atrazine @ } 1.0 \mathrm{~kg} \mathrm{a} \mathrm{i} \mathrm{ha}^{-1} \text { as PE } f b \\
\text { tembotrione @ } 60 \mathrm{~g}+2,4-\mathrm{D} \text { amine salt } \\
\text { @ } 290 \mathrm{~g} \text { a.i ha }{ }^{-1} \text { as PoE }\end{array}$ & 9.20 & 7.93 & 8.04 & 19 & 56 \\
\hline $\begin{array}{l}\mathrm{T}_{7} \text { : Atrazine @ } 1.0 \mathrm{~kg} \mathrm{a.i} \mathrm{ha}^{-1} \text { as PE } f b \\
\text { topramezone @ } 15 \mathrm{~g}+2,4-\mathrm{D} \text { amine salt } \\
\text { @ } 290 \mathrm{~g} \text { a.i ha }^{-1} \text { as PoE }\end{array}$ & 8.05 & 7.91 & 9.30 & 931 & 915 \\
\hline $\begin{array}{l}\mathrm{T}_{8} \text { : Atrazine @ } 1.0 \mathrm{~kg} \mathrm{a.i} \mathrm{ha}^{-1} \text { as PE } \mathrm{fb} \\
\text { halosulfuron methyl @ } 34 \mathrm{~g} \mathrm{a.i} \mathrm{ha}^{-1}+ \\
\text { 2,4-D amine salt @ } 290 \mathrm{~g} \mathrm{a.i} \mathrm{ha} \text { has PoE }^{-1} \text { as }\end{array}$ & 6.88 & 0.30 & 0.90 & 928 & 912 \\
\hline $\begin{array}{l}\text { T9: Hand weeding twice at } 15 \text { and } 30 \\
\text { DAS }\end{array}$ & 42.6 & 41.8 & 42.2 & 780 & 719 \\
\hline $\mathrm{T}_{10}:$ Weedy check & 41.5 & 37.5 & 37.8 & 795 & 777 \\
\hline C.D $(P=0.05)$ & 38.4 & 36.9 & 43.2 & 938 & 666 \\
\hline SEm \pm & 33.6 & 0.94 & 2.81 & 29 & 85 \\
\hline
\end{tabular}

Among the different weed management practices higher yield attributes and kernel yield of maize was recorded with hand weeding twice at 15 and 30 DAS $\left(\mathrm{T}_{9}\right)$, which was however comparable with application of atrazine @ $1.0 \mathrm{~kg} \mathrm{a.i} \mathrm{ha}{ }^{-1}$ as pre emergence $f b$ topramezone @ 30 g a.i ha ${ }^{-1}$ as post emergence $\left(\mathrm{T}_{3}\right)$, atrazine @ $1.0 \mathrm{~kg}$ a.i ha ${ }^{-1}$ as pre emergence $f b$ tembotrione @ $120 \mathrm{~g} \mathrm{a} . \mathrm{i} \mathrm{ha}^{-1}$ as post emergence $\left(\mathrm{T}_{2}\right)$, atrazine @ $1.0 \mathrm{~kg}$ a.i $\mathrm{ha}^{-1}$ as pre emergence $f b$ one HW at 30 DAS
$\left(\mathrm{T}_{1}\right)$, without any significant disparity among them. The results corroborates with the findings of Rao et al., (2016) and Pratap et al., (2012).

However atrazine @ $1.0 \mathrm{~kg}$ a.i ha ${ }^{-1}$ as pre emergence $f b$ topramezone @ 15g + 2,4-D amine salt @290 g a.i ha ${ }^{-1}$ as post emergence $\left(\mathrm{T}_{7}\right)$ and atrazine @ $1.0 \mathrm{~kg}$ a.i ha ${ }^{-1}$ as pre emergence $f b$ tembotrione @ 60g + 2,4-D amine salt @ $290 \mathrm{~g} \mathrm{a.i} \mathrm{ha}^{-1}$ as post emergence 
$\left(\mathrm{T}_{6}\right)$ were statistically comparable with one another and were significantly superior to atrazine @ $1.0 \mathrm{~kg} \mathrm{a.i} \mathrm{ha}{ }^{-1}$ as pre emergence $f b$ halosulfuron methyl @67.5 $\mathrm{g}$ a.i ha $^{-1}$ as post emergence $\left(\mathrm{T}_{4}\right)$ and atrazine @ $1.0 \mathrm{~kg}$ a.i ha ${ }^{-1}$ as pre emergence $f b$ 2, 4- D amine salt @580 $\mathrm{g}$ a.i ha ${ }^{-1}$ as post emergence $\left(\mathrm{T}_{5}\right)$, which inturn were comparable with one another.

The increase in yield attributes and yield under various weed management practices might be due to reduced weed density and dry weight, there by reduced crop weed competition thus provided congenial environment for the crop for better expression of vegetative and reproductive potential. The lowest yield attributes and kernel yield of maize was resulted with control $\left(\mathrm{T}_{10}\right)$. The lowest kernel yield of maize was due to stiff competition from weeds resulting in poor source and sink development with poor yield contributing characters and yield. The results were in accordance with the findings of Rasool et al., (2016) and Mitra et al., (2018) (Table 1).

\section{Effect of weed management practices on succeeding greengram}

Yield attributes and seed yield of greengram differed significantly due to different weed management practices performed in maize (Table 2). The higher yield attributes and seed yield of greengram was recorded with hand weeding twice at 15 and 30 DAS $\left(\mathrm{T}_{9}\right)$, which was closely followed by application of atrazine @ $1.0 \mathrm{~kg} \mathrm{a.i} \mathrm{ha}{ }^{-1}$ as pre emergence $f b$ one HW at 30 DAS $\left(\mathrm{T}_{1}\right)$, atrazine @ $1.0 \mathrm{~kg}$ a.i $\mathrm{ha}^{-1}$ as pre emergence $f b$ topramezone @30 g a.i ha ${ }^{-1}$ as post emergence $\left(\mathrm{T}_{3}\right)$, atrazine @ 1.0 $\mathrm{kg}$ a.i ha ${ }^{-1}$ as pre emergence $f b$ tembotrione @ $120 \mathrm{~g}$ a.i ha ${ }^{-1}$ as post emergence $\left(\mathrm{T}_{2}\right)$ and atrazine @ $1.0 \mathrm{~kg} \mathrm{a.i} \mathrm{ha-1}$ as pre emergence $f b$ halosulfuron methyl @67.5 g a.i ha ${ }^{-1}$ as post emergence $\left(\mathrm{T}_{4}\right)$, which in turn were comparable with one other.
The lowest yield attributes and seed yield was recorded with control $\left(\mathrm{T}_{10}\right)$, which was significantly lower than atrazine @ $1.0 \mathrm{~kg}$ a.i $\mathrm{ha}^{-1}$ as pre emergence $f b$ topramezone @ 15g + 2,4-D amine salt@ $@ 290 \mathrm{~g} \mathrm{a.i} \mathrm{ha}{ }^{-1}$ as post emergence $\left(\mathrm{T}_{7}\right)$, atrazine @ $1.0 \mathrm{~kg}$ a.i ha ${ }^{-1}$ as pre emergence $f b$ tembotrione @ 60g + 2,4-D amine salt @290 g a.i ha ${ }^{-1}$ as post emergence $\left(\mathrm{T}_{6}\right)$, atrazine @ $1.0 \mathrm{~kg}$ a.i ha ${ }^{-1}$ as pre emergence $f b$ 2, 4- D amine salt @ $580 \mathrm{~g} \mathrm{a.i}$ $\mathrm{ha}^{-1}$ as post emergence $\left(\mathrm{T}_{5}\right)$ and atrazine @ 1.0 $\mathrm{kg}$ a.i ha ${ }^{-1}$ as pre emergence fb halosulfuron methyl@ 34 g a.i ha ${ }^{-1}+2,4-D$ amine salt @ $290 \mathrm{~g}$ a.i ha ${ }^{-1}$ as post emergence $\left(\mathrm{T}_{8}\right)$ and each of which maintained parity among themselves. From the above experiment it may be concluded that atrazine@ $1.0 \mathrm{~kg} \mathrm{a.i} \mathrm{ha}{ }^{-1}$ as pre emergence $f b$ topramezone @ $30 \mathrm{~g} \mathrm{a.i} \mathrm{ha}^{-1}$ as post emergence $\left(\mathrm{T}_{3}\right)$ or atrazine @ $1.0 \mathrm{~kg}$ a.i $\mathrm{ha}^{-1}$ as pre emergence $f b$ tembotrione @ $120 \mathrm{~g}$ a.i ha ${ }^{-1}$ as post emergence $\left(\mathrm{T}_{2}\right)$ were the best weed management practices at the times of labour shortage for effective weed control and higher yield of maize and succeeding greengram.

\section{References}

Baghestani, M.A., Eskandar,Z.,Ali,s Saeid,S. 2007. Efficacy evaluation of some dual purpose herbicides to control weeds in maize (Zea mays L.). Crop Protection. 26(7): 936-942.

Dass, S. S., Jat, M. L., Singh, K. P and Rai, H.K. 2008. Agro-economic analysis of maize based cropping systems in India. Indian Journal of fertilizers. 4 (4): 5362.

Gomez, K.A and Gomez, A.A. 1984. Text book on Statistical procedures in agricultural research. New York Chichester Wiley. 2nd edition. Pp-680.

Imoloame, E.O and Omolalye, J.O. 2016. Impact of different periods of weed interference on the growth and yield of maize (Zea Mays L.). Tropical 
Agriculture. 93(4): 245-257.

Mitra, B., Bhattacharya, P.M., Ghosh, A., Patra, K., Chowdhury, A.K and Gathala, M.K. 2018. Herbicide options for effective weed management in zero-till maize. Indian Journal of Weed Science. 50(2): 137-141.

Nidhi,S., Komal, B. B., Lal, P.A., Bahadur, K. $\mathrm{T}$ and Narayan, A. 2015. Weed dynamics and productivity of spring maize under different tillage and weed management methods. Azarian Journal of Agriculture. 2(5). 118-122.

Panse, V.G and Sukhatme, P.V. 1985. Statistical methods for agricultural workers. Indian Council of Agricultural Research, New Delhi.

Pradeep, R., Sreenivas, G and Leela Rani, P. 2017. Impact of sustainable weed management practices on growth, phenology and yield of rabi grain maize (Zea mays L.) International Journal of current microbiology and Applied sciences. 6(7): 701-710.
Pratap, S.V., Guru, S.K., Kumar, A., Akshita, B and Tripathi, N. 2012. Bioefficacy of tembotrione against mixed weed complex in maize. Indian Journal of Weed Science. 44(1): 1- 5.

Rao, C.H.R., Prasad, P.V.N and Venkateswarlu, B. 2016. Assesment of different herbicides on yield and economics of kharif maize (Zea mays L.). International Journal of Agricultural Science and Research. 6(6): 409-414.

Rasool, S and Khan, M.H. 2016. Growth and yield of maize (Zea mays L.) as influenced by integrated weed management under temperate conditions of North Western Himalayas. American Journal of Experimental Agriculture. 14 (1): 1-9.

Yogita, G., Singha, P.K., Dubeya, R.P and Guptab, P.K. 2018. Assessment of yield and economic losses in agriculture due to weeds in India. Crop Protection. 107: 12-18.

\section{How to cite this article:}

Sandhya Rani, B., V. Chandrika, G. Prabhakara Reddy, P. Sudhakar, K. V. Nagamadhuri and Karuna Sagar, G. 2019. Effect of Weed Management Practices in Rabi Maize and their Residual Effect on Succeeding Greengram. Int.J.Curr.Microbiol.App.Sci. 8(12): 831-837. doi: https://doi.org/10.20546/ijcmas.2019.812.107 